\title{
Polymorphic Post-Transplant Lymphoproliferative Disorder
}

National Cancer Institute

\section{Source}

National Cancer Institute. Polymorphic Post-Transplant Lymphoproliferative Disorder. NCl Thesaurus. Code C7183.

A clonal B-cell lymphoproliferative disorder arising as a result of post-transplant immunosuppression therapy. It is characterized by destructive infiltration of lymph nodes and extranodal sites by a polymorphic B-cell infiltrate composed of small and medium sized lymphocytes, immunoblasts, and plasma cells. In some cases, reduction of the immunosuppression therapy may lead to regression of the lesions. In other cases the lesions may progress to lymphoma. 